\title{
THE STUDY OF INFLUENCE OF HEAT TREATMENT PROCEDURES ON STRUCTURE AND PROPERTIES OF THE NEW HIGH-STRENGTH STEEL WITH INCREASED COLD RESISTANCE
}

\author{
P. P. Poletskov ${ }^{1}$, A. S. Kuznetsova ${ }^{1}$, O. A. Nikitenkoํ, D. Yu. Alekseev ${ }^{1}$ \\ ${ }^{1}$ Nosov Magnitogorsk State Technical University (Magnitogorsk, Russia) \\ E-mail: allakuznetsova.mgtu@mail.ru; o.nikitenko@magtu.ru
}

\section{AUTHOR'S INFO}

P. P. Poletskov, Dr. Eng., Prof., Dept. of Metal Processing Technology;

A. S. Kuznetsova, Senior Lecturer, Materials Processing Dept.;

O. A. Nikitenko, Associate Prof., Materials Processing Dept

D. Yu. Alekseev, Scientific Researcher,

Termodeform-MGTU Engineering Center

\section{Key words:}

new high-strength steel, heat treatment, quenching, tempering, microstructure, increased cold resistance, mechanical properties, hardness, impact strength.

\begin{abstract}
A B S T RACT
The study of influence of different heat treatment procedures on microstructure and mechanical properties of the new high-strength weldable cold-resistant steel 20G2SMRA (20Г2CMPA) is conducted. Morphology of martensite after steel quenching, as well after quenching and consequent tempering, is examined using optical metallography and electron microscopy. Regularities of varying of microstructure parameters, hardness values $\left(\mathrm{HV}_{1}\right)$ and impact strength $\mathrm{KCV}$ were revealed in this work at the temperature $-60{ }^{\circ} \mathrm{C}$ depending on heating temperature for quenching and consequent tempering. Amount of residual austenite after quenching starting from the temperatures 850,950 and $1000{ }^{\circ} \mathrm{C}$ was determined using X-ray structural phase analysis. The rational procedure of heat treatment was established as a result of the study; it provides combination of guaranteed yield strength $\sigma_{0,2} \geq 600 \mathrm{~N} / \mathrm{mm}^{2}$ together with low-temperature impact strength $\mathrm{KCV}^{-60} \geq 50 \mathrm{~J} / \mathrm{sm}^{2}$ and ductility $\delta_{5} \geq 17 \%$. The obtained results of investigation are aimed for commercial putting into practice in the conditions of heavy plate production at 5000 rolling mill of Magnitogorsk Iron and Steel Works (MMK).
\end{abstract}

\section{Introduction}

Taking into account exploration of hardly accessible northern and Arctic regions, necessity in high-strength coldresistance weldable steels rises. Such steels are aimed to be used for modernization of equipment for mining and building industries. These industries are characterized by high level of requirements in the areas of decrease of metal consumption and manufacturing expenses, as well as of increase of lifting capacity, reliability and service life of corresponding equipment. Respectively, the complex properties are required for mechanical parameters of materials used for fabrication of welding elements of a frame construction. The following properties can be mentioned here: high strength (600$1100 \mathrm{~N} / \mathrm{mm}^{2}$ ) with reservation of sufficient level of tough and ductile parameters at low temperatures $\left(\mathrm{KCV}^{-60} \geq 50 \mathrm{~J} / \mathrm{sm}^{2}\right)$ as well as weldability $\left(C_{e q} \leq 0.53\right)[1-6]$.

The up-to-date concept of development of the new high-strength cold-resistant steels with preset complex of properties includes microalloying of steels in combination with varying heat treatment procedures [7-11]. The world and national practice testifies that heavy plates of high-strength weldable steels with tensile strength more than $600 \mathrm{MPa}$ combined with low-temperature toughness are supplied mainly in thermally improved state [12-16].

Elimination of any restrictions for dimension range for thickness more than $20 \mathrm{~mm}$ with minimal steel alloying degree [12] is the main advantage of quenching and high tempering technology in comparison with thermomechanical treatment, in particular for mastering of new steel rolled products with thickness $8-50 \mathrm{~mm}$. At the same time optimal combination of strength and toughness can be provided in the case when steel hardness after quenching will exceed minimal allowable values, what is possible if martensite is presented in the amount not less than $90 \%$ in the structure of quenched steel [14, 17-21].

It should be mentioned that tempering temperature choice should provide reaching of the required low-temperature impact strength in combination with satisfactory parameters of strength and ductility [20].

Thereby, the aim of this work can be formulated as study of influence of heat treatment procedures (quenching and tempering) on structure and properties of the new high-strength steel with increased cold resistance.

\section{Materials and methods of investigation}

The samples of the newly developed steel of 20G2SMRA (20Г2CMPA) grade with chemical composition presented in the Table 1 were the material for this research [22]. 
Melting, rolling and consequent heat treatment of experimental sheet samples with thickness $15 \mathrm{~mm}$ were conducted on the base of the Scientific and production complex "Engineering center Termodeform-MGTU" and the Center of collective usage of the Scientific and research institute "Nanosteels" at Nosov Magnitogorsk State Technical University.

The critical points were determined using the method of differential scanning calorimetry (DSC) on the sensor of synchronous thermal analysis (STA) Jupiter 449 F3 (NETSCH) with speed $10^{\circ} \mathrm{C} / \mathrm{min}$ up to the temperature $1000{ }^{\circ} \mathrm{C}$ in argon medium with purity $99.998 \%$, as well as using complex dilatometric analysis with assistance of the research complex Gleeble 3500 [12].

The temperature procedures of quenching and tempering were varied in the following ranges:

- quenching temperature was consequently increased from $\mathrm{Ac}_{3}+30{ }^{\circ} \mathrm{C}$ to $T_{\max }=1000{ }^{\circ} \mathrm{C}$ with interval $50{ }^{\circ} \mathrm{C}$ (holding at quenching temperature $2.5 \mathrm{~min} / \mathrm{mm}$ ); cooling after quenching was conducted in water;

- tempering temperature was varied from 200 to $600^{\circ} \mathrm{C}$ with interval $100{ }^{\circ} \mathrm{C}$ (duration of holding is $2.5 \mathrm{~min} / \mathrm{mm}$ $+25 \mathrm{~min}$ ).

After heat treatment (quenching, quenching and tempering) the samples for mechanical testing and metallographic researches were made.

To provide microanalysis, the polished sections were manufactured from the samples via the standard technique; it was provided via pressing of samples in "Transoptic" tar at automatic press Simplimet 1000 within the sample preparation line of Buechler company. To reveal microstructure, the surface of polished sections was subjected to pickling in $4 \%$ solution of nitric acid in ethyl alcohol via dipping of polished surface in the bath with the chemical agent. Qualitative and quantitative analysis was conducted using light microscope Axio Observer (Zeiss) with magnification 50-1000 times, with assistance of software for processing of metallographic images Thixomet PRO as well as scanning electron microscope (SEM) JSM 6490 LV.

To reveal the boundaries of the former austenite grain, pickling of polished sections in freshly prepared solution of picric acid was used, while (1-10)\% of surface active substances were added in this solution and the chemical agent was heated to $(50-70){ }^{\circ} \mathrm{C}$ [23]. Average value of austenite grain was determined manually, by linear measurements using the programs with built-in techniques adapted in correspondence with requirements of GOST 8233-56 and GOST 5639-82 standards.

Pattern cutting and surface processing for extension, hardness and impact bending tests were conducted in correspondence with the requirements of GOST 7564-97

\begin{tabular}{|l|c|c|c|}
\hline \multicolumn{3}{|l|}{ Table 2. The measurement results for steel critical points } \\
\hline \multirow{2}{*}{ Steel grade } & \multirow{2}{*}{$\begin{array}{c}\text { Examination } \\
\text { method }\end{array}$} & $A_{c 1}$ & $A_{c 3}$ \\
\cline { 3 - 4 } & Temperature of critical points $t{ }^{\circ} \mathrm{C}$ \\
\hline \multirow{2}{*}{ 20G2SMRA } & DSC & 725 & 814 \\
\cline { 2 - 4 } & Dilatometer & 730 & 820 \\
\hline
\end{tabular}

standard. The number of samples for each type of testing was varied from 3 to 6 and then the average value was calculated.

Impact bending tests were conducted at the impact testing machine RKP 450 in correspondence with the requirements of GOST 9454-78 standard on transversal samples with size $10 \times 10 \mathrm{~mm}$, having $\mathrm{V}$-shaped notch, after quenching and consequent tempering separately. The tested samples were cooled down to $-60{ }^{\circ} \mathrm{C}$ in stabilizing cooling bed LAUDA master PL1.

Hardness was measured via Vickers method in correspondence with the requirements of GOST 9450-60 standard: by indentation of a diamond pyramid having the angle $136^{\circ}$ between the opposite planes, using hardness tester Buehler Micromet with $1 \mathrm{~kg}$ load.

Qualitative and quantitative phase analysis of residual austenite was conducted via X-ray structural method based on comparison of lines intensity in determining phases, using X-ray diffractometer of Shimadzu company, the model XRD-7000.

\section{Results of investigation}

Based on the results of differential scanning calorimetry (DSC) and dilatometric analysis for the new steel grade 20G2SMRA, the values of critical points were determined (Table 2) [22].

\section{The results of quenching temperature influence on steel structure and properties}

It was established on the base of optical microscopy, that the examined steel 20G2SMRA has the structure of massive (lath) martensite in all cases after quenching from temperatures from $850{ }^{\circ} \mathrm{C}$ до $1000{ }^{\circ} \mathrm{C}$; this structure is formed via shifting diffusion-free mechanism of transversal slipping (Fig, 1, $a-b$ ). Rise of austenitization temperature leads to increase of the average size of martensite massifs and lathes, heterogeneity in their dimensional distribution is strengthening as well.

The analysis conducted using SEM (Fig. 1, $c, d$ ) displayed that lath martensite $\left(M_{l}\right)$ with volumetric part exceeding $70 \%$ is a dominant morphological component in the structure of $\alpha$-phase of 20G2SMRA steel. Square of martensite massifs increases from 20 to $500 \mu \mathrm{m}^{2}$ with rising of the heating temperature for quenching. Width of single lathes consisting a massif varies within the range from 150 to $300 \mathrm{~nm}$. Total amount of lathes in a massif varies from $4-6$ to $12-16$.

Additionally, there are single plates that can be met in the structure, with their transversal size several times exceeding width of single lathes in massive martensite and reaching 1-3 $\mu \mathrm{m}$ (see Fig. 1, $d$ ). Length of these plates makes appr. $30 \mu \mathrm{m}$. Such morphology can be identified as plate martensite $\left(M_{p}\right)$, and its presence stipulates lowering of stresses amplitude and, consequently, decrease of the risk of quenching cracks formation.

The results of researches on regularity of varying of steel microstructure parameters (real size of former aus- 

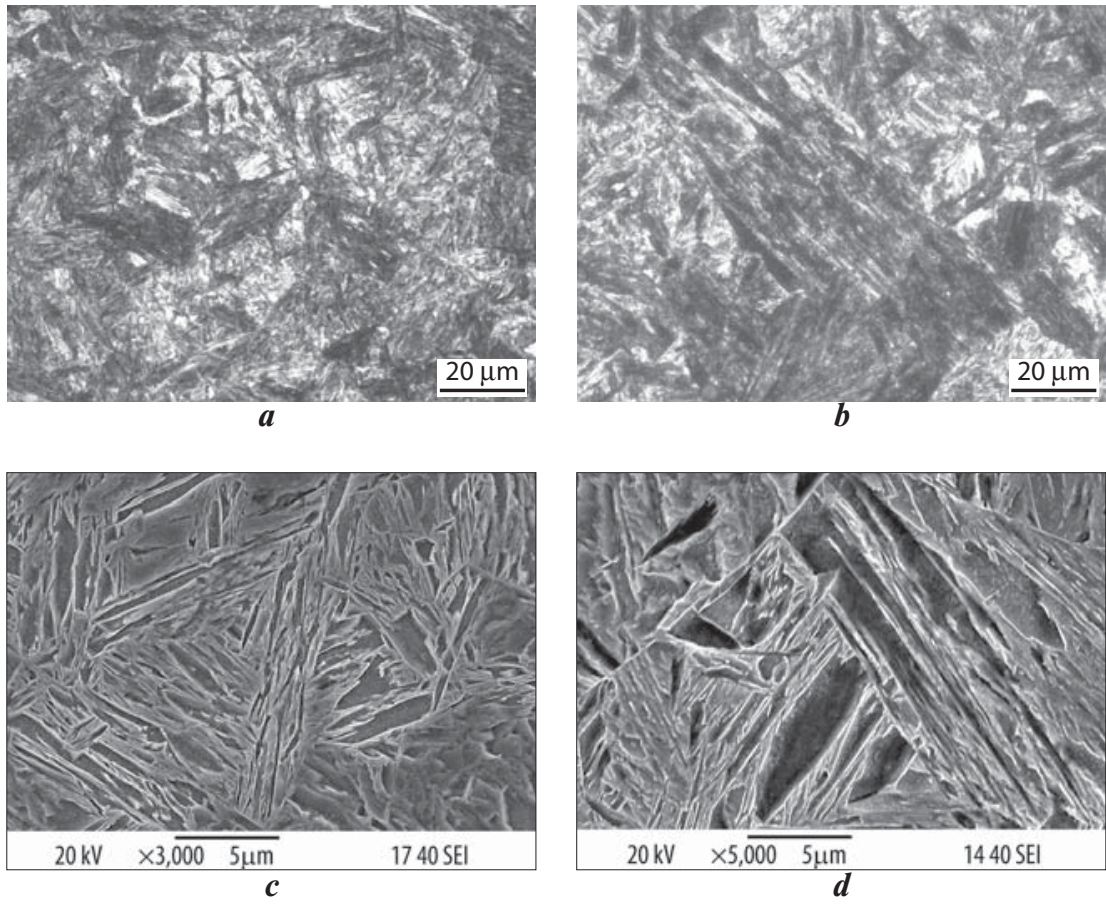

Fig. 1. Steel microstructure after quenching from temperature: $850{ }^{\circ} \mathrm{C}(a, c)$ and $1000^{\circ} \mathrm{C}(b, d)$ :

$a, b-$ light microscopy; $c, d-\mathrm{SEM}$

tenite grain) depending on quenching temperature as well as microstructure relationship with mechanical properties are presented on the Fig. 2.

The obtained data (see Fig. 2) testify that the minimal grain size is observed in the interval $16-18 \mu \mathrm{m}$ (grain No. 9). Observed enlargement of structural parameters informs about increase of the size of real austenite grain (No. of grain varies from 8 to 5), connected with rise of austenitization temperature; it stipulates lowering of impact toughness in steel within the temperature interval $850-1000{ }^{\circ} \mathrm{C}$.

The values of hardness $\mathrm{HV}_{1}$ depending on the heating temperature for quenching almost does not vary. Such results can be explained in the following way: austenite enrichment with carbon does not occur in hypoeutectoid steels within the interval above $\mathrm{Ac}_{3}$ point; consequently, the amount of residual austenite in steel does not vary with rise of the heating temperature for quenching. These con-

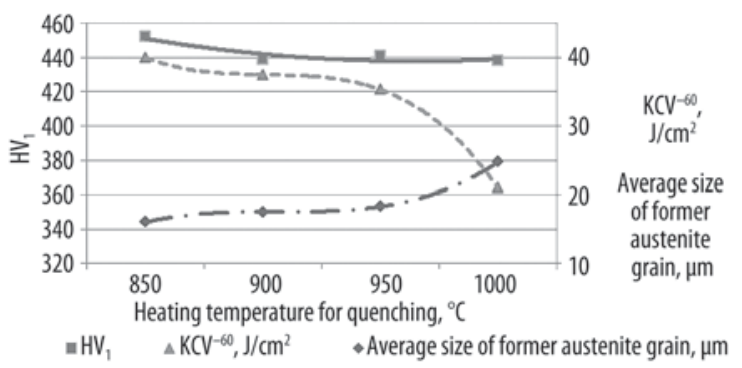

Fig. 2. Relationship between the average size of former austenite grain, impact strength $\mathrm{KCV}^{-60}$ and hardness $\mathrm{HV}_{1}$ (from one side) and the heating temperature for quenching (from other side) clusions are confirmed by the results of qualitative and quantitative phase analysis (conducted by X-ray structural method) of residual austenite in the samples at the heating temperatures for quenching 850,950 and $1000{ }^{\circ} \mathrm{C}$. The diffraction pattern (Fig. 3) displays typical maximum, corresponding to planecentered crystal lattice for all examined samples; at the same time relative intensity of this maximum for the samples quenched at different temperatures is characterized by approximately equal level [24]. Quantitative evaluation of residual austenite displayed $\sim 0,4-0,8 \%$ for samples quenched at 850,950 and $1000^{\circ} \mathrm{C}$.

It was determined on the base of experimental investigation that reaching the maximal values of impact strength $\mathrm{KCV}^{-60}$ in combination with satisfactory values of hardness $\mathrm{HV}_{1}$ for steel 20G2SMRA is provided at the heating temperature for quenching appr. $\sim 850^{\circ} \mathrm{C}$.

\section{The results of tempering temperature influence on steel structure and properties}

It was established during the research that qualitative variation of martensite morphology does not occur within the tempering temperature interval from 200 to $500{ }^{\circ} \mathrm{C}$ (Fig. 4, $a-c$ ) and lath structure of $\alpha$-phase is observed to $500^{\circ} \mathrm{C}$. However, rise of tempering temperature is accompanied by the most strong distortion of form and structure of boundaries of lathes, what is stipulated by formation of fragmented substructure owing to relaxation of defect structure (formed in the process of $\gamma \rightarrow \alpha$ transformation) and rebuilding of dislocation structure.

Additionally, this process is accompanied by extraction of carbide phase particles, while the initial stage of the most intensive decomposition of oversaturated solid solution is

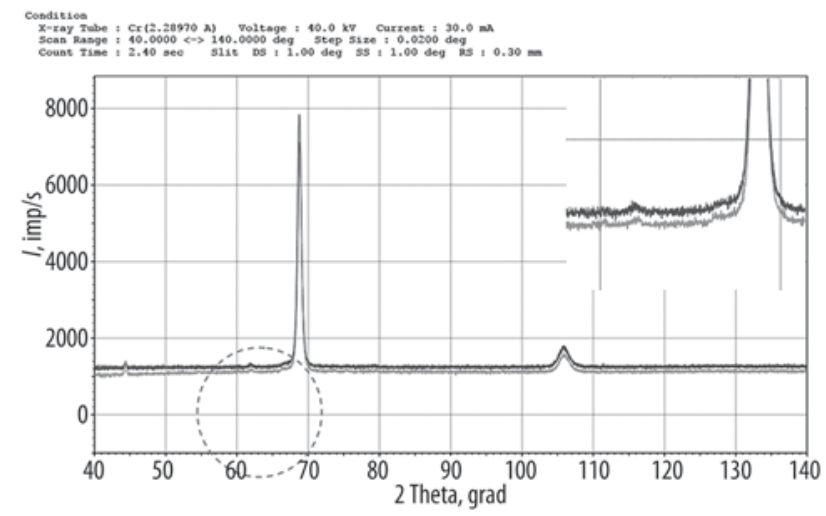

Fig. 3. Relationship between intensity of maximal values $I$ (imp/s) and Bragg angle 2 Theta (grad) for the samples from steel 20G2SMRA quenched in water at 850,950 and $1000{ }^{\circ} \mathrm{C}$ 

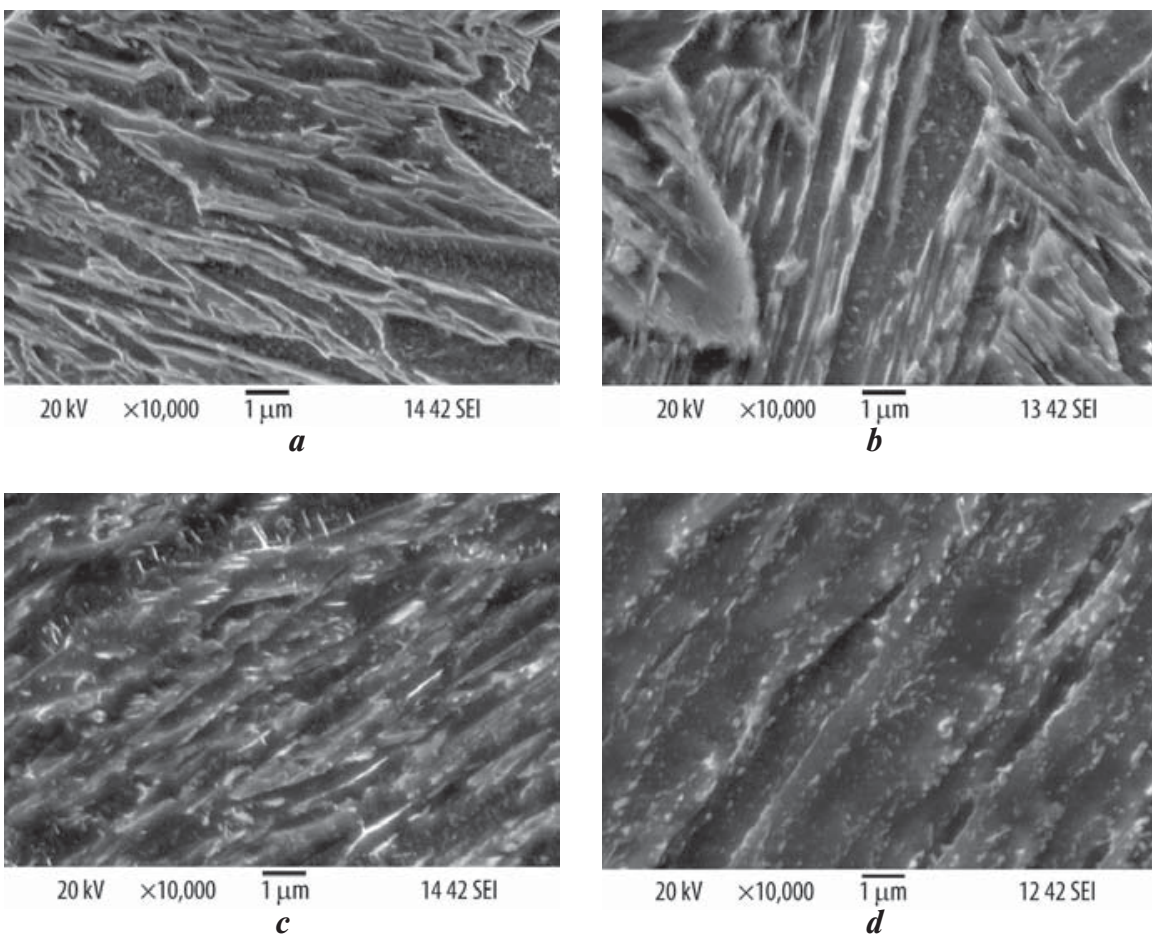

Fig. 4. Steel microstructure after quenching from $850{ }^{\circ} \mathrm{C}$ and consequent tempering at the temperatures $200{ }^{\circ} \mathrm{C}(a), 400{ }^{\circ} \mathrm{C}(b), 500^{\circ} \mathrm{C}(c), 600{ }^{\circ} \mathrm{C}(d){ }^{\circ} \mathrm{C}$; SEM from 500 to $600{ }^{\circ} \mathrm{C}$ is not accompanied by lowering of impact strength, owing to Mo presence in the steel.

Variation of tempering temperature within the temperature interval from 400 to $600{ }^{\circ} \mathrm{C}$ leads to essential lowering of hardness values approximately by 1.5 times, what is stipulated by decrease of the value of internal stresses. At the same time temperature rise is accompanied by increase of lowtemperature impact strength for 20G2SMRA steel.

Thereby it was revealed on the base of obtained regularities (see Fig. 2,5) that the following processing procedure is satisfied to preset requirement for the new steel grade 20G2SMRA: quenching from 850 ${ }^{\circ} \mathrm{C}$ with consequent high tempering at the temperature $600{ }^{\circ} \mathrm{C}$.

The developed technology (sparingly alloyed chemical composition of 20G2SMRA steel [18] and procedures of heat treatment)

fixed at $300{ }^{\circ} \mathrm{C}$ with consequent rise of the temperature of tough-brittle transition. Coagulation and spheroidizing of carbide particles is observed at the tempering temperature at $500{ }^{\circ} \mathrm{C}$ and above it; these particles provide variation of morphology in $\alpha$-phase and structure of tempered steel in the following consequence: tempering martensite $\rightarrow$ tempering troostite $\rightarrow$ tempering troostite-sorbite $\rightarrow$ tempering sorbite that becomes the dominant structural component at the tempering temperature $600{ }^{\circ} \mathrm{C}(\mathbf{F i g} . \mathbf{4}, d)$.

The preset tempering temperature was determined on the base of its influence on structural variations and, consequently, on $\mathrm{HV}_{1}$ hardness and $\mathrm{KCV}^{-60}$ impact toughness parameters (Fig. 5).

This figure testifies that lowering of the values of KCV-60 impact toughness relating to quenched state is observed on the background of rather monotonous decrease of $\mathrm{HV}_{1}$ hardness within the temperature interval from 200 to $400{ }^{\circ} \mathrm{C}$; it means about development of irreversible tempering brittleness. Tempering within the temperature interval

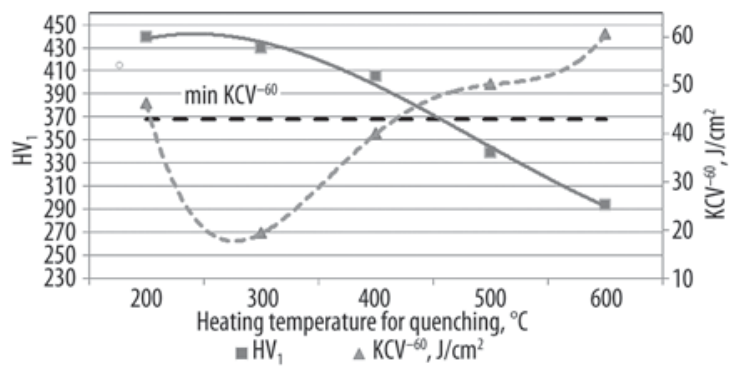

Fig. 5. Influence of tempering temperature on determination of $\mathrm{HV}_{1}$ hardness and $\mathrm{KCV}-60$ impact strength for 20G2SMRA steel is suggested for pilot and industrial testing applying to the conditions of heavy plate production at 5000 rolling mill of Magnitogorsk Iron and Steel Works (MMK).

\section{Conclusions}

Based on the conducted researches of the new weldlarities of variation of microstructural parameters and mechanical properties were obtained depending on heating temperature for quenching and consequent tempering.

It was established that the following procedure is considered as the optimal heat treatment of plate steel of 20G2SMRA grade:

- quenching from $850 \pm 20{ }^{\circ} \mathrm{C}$ temperature during $25 \mathrm{~min}$, when combined structure is forming; this structure consists of lath martensite (70\%) and high-temperature plate martensite (about 30\%) and provides reaching of maximal values of impact strength $\left(\mathrm{KCV}^{-} 60=40 \mathrm{~J} / \mathrm{cm}^{2}\right)$ with satisfactory hardness $\left(\mathrm{HV}_{1}=452\right)$;

- consequent high tempering at the temperature $600{ }^{\circ} \mathrm{C}$ during $40 \mathrm{~min}$, when tempering sorbite structure is formed; it provides guaranteed reaching of the required combination of hardness $\left(\mathrm{HV}_{1}=291\right)$ and impact strength $\left(\mathrm{KCV}^{-60}=61 \mathrm{~J} / \mathrm{cm}^{2}\right)$.

Mechanical properties of pilot and experimental samples meet all requirements of standards and specifications for such products. Providing of this favourable combination of strength and toughness parameters at the testing temperatures down to $-60^{\circ} \mathrm{C}$ makes it possible to use steel of 20G2SMRA grade in constructions operating in the conditions of Far North regions. able cold-resistant steel of 20G2SMRA grade, the regu- 
The work was done under financial support of the $R F$ Ministry of Education and Science within the framework of execution of the grant of RF President (Agreement No. 075-15-2020-205 dated 17.03.2020 (int. No. MK1979.2020.8)).

\section{REFERENCES}

1. Solntsev Yu. P., Titova T. I. Steels for the North and Siberia. $\mathrm{SPb}$. Khimizdat. 2002. 352 p.

2. Khlusova E. I., Sych O. V. Development of cold-resistant structural materials for Arctic region. History, experience, upto-date state. Innovatsii. 2018. No. 11 (241). pp. 85-92.

3. Stolyarov V. I., Nikitin V. N., Efron L. I., Lazko V. G. State and development prospects of technology and composition of high-strength weldable steels with yield strength $700 \mathrm{~N} / \mathrm{mm}^{2}$. Stal. 1993. No. 6. pp. 61-67.

4. Chukin M. V., Poletskov P. P., Gushchina M. S. et al. Development of import replacing technology for manufacture of rolled strip of high-strength structural steel for northern application. Proizvodstvo prokata. 2019. No. 4. pp. 5-11.

5. Lv Z., Qian L., Liu S., Zhan L., Qin S Preparation and Mechanical Behavior of Ultra-High Strength Low-Carbon Steel. Materials. 2020. Vol. 13. No. 2. p. 459.

6. Oryshchenko A. S., Malyshevskii V. A., Petrov S. N., Shumilov E. A. Relation Between the Degree of Alloying, Structure, and Mechanical Properties of High-Strength Steel. Steel in Translation. 2018. Vol. 48. No. 3. pp. 143-148.

7. Solntsev Yu. P. Cold-resistant steels and alloys. A manual for high schools. SPb. Khimizdat. 2005. 480 p.

8. Meyer L. W., Pursche F. Modern high strength low alloyed steels. Proceedings of the 1st International Conference about Recent Trends in Structural Materials COMAT 2010. 2010. pp. 13-18.

9. Sych O. V. Scientific-technological grounds of development of cold-resisting steels with guaranteed yield strength 315$750 \mathrm{MPa}$ for Arctics. Part 1. Alloying principles and requirements to the structure of rolled sheets. Voprosy materialovedeniya. 2018. No. 3 (95). pp. 22-47.

10. Subhani A. R., Mondal D. K., Maity J., Mondal C., Roy H. Development of a High-Strength Low-Carbon Steel with Reasonable Ductility Through Thermal Cycling. Journal of Materials Engineering and Performance. 2019. Vol. 28. No. 4. pp. 2192-2201.
11. Thiessen R. G., Paul G., Sebald R. with enhanced mechanical parameters. Chernye metally. 2019. No. 8. pp. 51-55.

12. Salganik V. M., Poletskov P. P., Gushchina M. S. et al. Features of fabrication of nano-structural high-strength rolled sheets. Vestnik Gomelskogo gosudarstvennogo tekhnicheskogo universiteta im. P. O. Sukhogo. 2015. No. 1 (60). pp. 27-30.

13. Gorynin I. V., Rybin V. V., Malyshevskiy V. A., Legostaev Yu. L., Semicheva T. G. The main aspects of development and use of high-strength structural steels. Voprosy materialovedeniya. 1999. No. 3 (20). pp. 7-20.

14. Nikitin V. N., Nastich S. Yu., Smirnov L. A. et al. Highstrength steels with sparingly alloying for quarry transport and mining equipment. Stal. 2016. No. 10. pp. 57-66.

15. Pontremoli M., Weber L., Dielg K., Schwinn F., Knauf G., Lippe M., Erhardt B., Finger M. High-strength steels for heavy plates, tubes and shapes. Chernye metally. 2006. No. 4. pp. 58-66.

16. Schröter F. Höherfeste Stähle für den Stahlbau - Auswahl und Anwendung. Bauingenieur. 2003. Vol. 78. Issue 9. pp. 426-432.

17. Kern A., Schriever U. Niobium in Quenched and Tempered HSLA-Steels. Dusseldorf : Verlag Stahleisen GmbH, 2005. pp. 109-119.

18. Yekh Ya. Heat treatment of steel. Directory. $3^{\text {rd }}$ edition. Translated from Czekh. M.: Metallurgiya. 1979. 264 p.

19. Juna H. J., Kanga J. S., Seob D. H., Kangb K. B., Park C. G. Effects of deformation and boron on microstructure and continuous cooling transformation in low carbon HSLA steels. Materials Science and Engineering. 2006. A 422. pp. 157-162.

20. Luxenburger G., Bockelmann M., Wolf P. et al. High Strength Quenched and Tempered (QT) Steels for Pressure Vessels. International Journal of Pressure Vessels and Piping. 2004. Vol. 81. No. 2. pp. 159-171.

21. Meskin V. S. Grounds of steel alloying. M.: Metallurgiya. 1964. $684 \mathrm{p}$.

22. Poletskov P. P., Nikitenko O. A., Kuznetsova A. S., Salganik V. M. The study of transformation kinetics for overcooled austenite of the new high-strength steel with increased cold resistance. CIS Iron and Steel Review. 2020. Vol. 19. pp. 56-59.

23. Poletskov P. P., Gushchina M. S., Alekseev D. Yu. et al. Study of influence of the procedure of tube steel controlled rolling on structural state of hot-deformed austenite. Vestnik Magnitogorskogo gosudarstvennogo tekhnicheskogo universiteta im. G. I. Nosova. 2018. Vol. 16. No. 3. pp. 67-77.

24. Sadovskiy V. D., Fokina E. A. Residual austenite in quenched steel. M.: Nauka. 1986. 113 p.

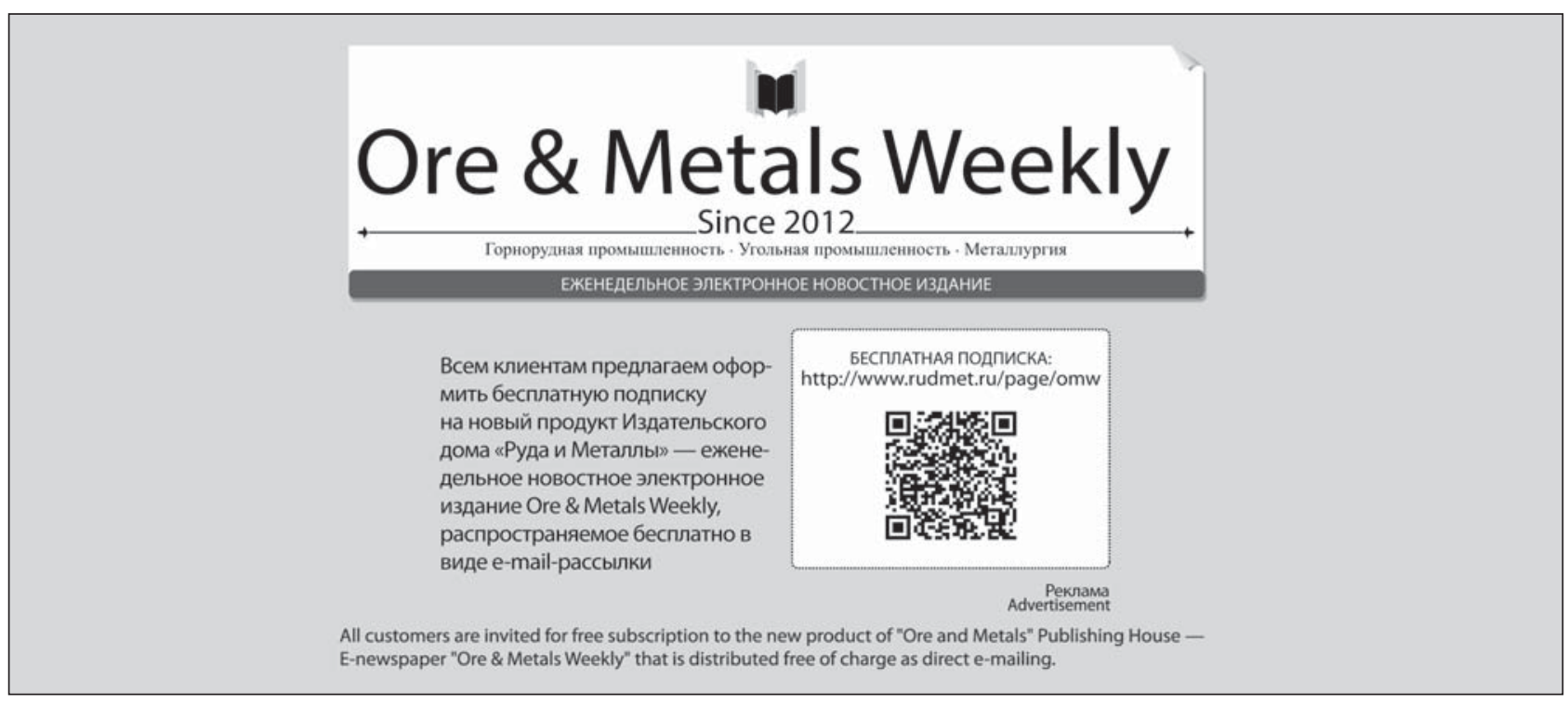

